THE POPULAR SCIENCE MONTHLY

THE SCIENCE PRESS

NEW YORK CITY: SUB-STATION 84

GARRISON, N. Y., AND LANCASTER, PA.

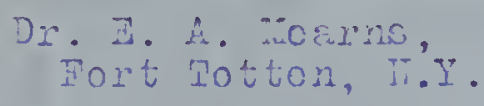

ninctecn hundred librarios.



THE POPULAR SCIENCE MONTHLY

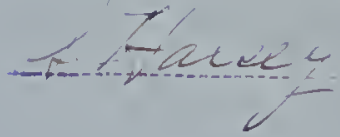

AOVERTISING WIANAGE

books in recent issues of The Popular Scicnce Monthly are :

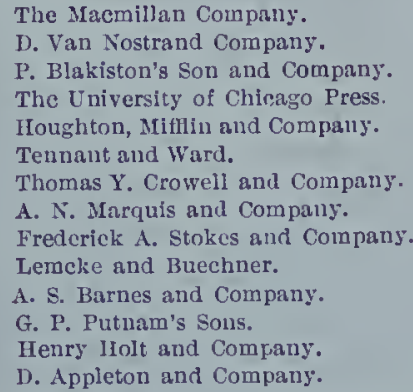

We trust that the lower advertising rates now offered will lead all publishers of standard books to use space regularly in The Popular Science Monthly. They can thus reaul most directly and at the lowest cost those who read, purcliase and recommend scientific books and those who huy staudard books of all kinds. We shall also welcome the cooperation of authors who appreciate the advantages of seeing their books advertised where they will be bronght to the attention of those interested.

\section{THE SCIENCE PRESS,} GARRISON, N. Y. LANoAster, Pa. NEW YORK : SUB-STATION 84

\section{The Popular Science Monthly \\ and the advertising of scientific books.}

The Popular Science Monthly is now the best place to adrertise scientific hooks. Since its cstahlishment in 1872 the SIonthlu has reached those people who are most likely to read and purchase books of a scientific cbaracter. Its former advertising charges of fifty dollars a page were not high considering the audience addressed. There are now good magazines with less than half the eirculation of the Monthly which charge those rates and good journals with one-tenth its circulation which charge half these rates.

But while The Popular Science Dronthly is stronger than ever before, its arlvertising rates have recently been reduced to $\$ 10$ net a page. This reduction has been made because we should rather print two hundred pages of publishers' announcements a year at $\$ 10$ a page than forty

\section{THE POPULAR SCIENCE MONTHLY}

Advertising Rates in effect September 1, 1906.

One page............................ $\$ 12$
Preferred position................. 18
Outside cover....................... 24

\section{DISCOUNTS}

12 pp.........33 1-3 per cent. 1 p.........16 2-3 per cent.

$6 \mathrm{pp} . . . \ldots . .30$ ". " 30 1-2 p..........10 ". "

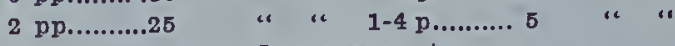
Less space net.

These discounts hold for space used within onc year. Thus the cost of one page is $\$ 10$ net whether used in one issuc or in four or more issues within one year. There are no other discounts or deductions of any kind or to any one. Terms net, 30 days.

The rates per insertion for space used within one year are :

$\begin{array}{lcrrr} & \text { ONEISSUE } & \text { TWO } & \text { SIX } & \text { TWELVE } \\ 1 \text { page } & \$ 10.00 & \$ 9.00 & \$ 8.40 & \$ 8.00 \\ 1-2 \text { “ } & 5.40 & 5.00 & 4.50 & 4.20 \\ 1-4 \text { “ } & 2.85 & 2.70 & 2.50 & 2.25 \\ 1-8 \text { " } & 1.50 & 1.43 & 1: 38 & 1.25 \\ 1 \text { inch } & .75 & .75 & .72 & .68\end{array}$

The size of the page is $8 \times 5 \frac{1}{2}$ inches.

Copy inust be received hefore the twelfth for insertion in the number puhlished on the twenty-fourth of cach month.

All advertisements are subject to approval.

THE SCIENCE PRESS NEW YORK CITY: SUB-STATION 84 GARRISON, N. Y., AND LANCASTER, PA. 
pages at $\$ 50$ a page. We want the advertisements because tliey are of interest to onr readers. They will tend to incrense still further our suhscription list, and this will add still further to the value of the advertising space.

The Popular Science Monthly is suhscribed for hy orer 1900 public lihraries; it is subscribed for or read by a majority of those in this countiy who liave my interest in science; it has the largest foreign circulation of any American scientific journal. If one quarter or oue tenth of those who read the Monthly purchase a book its snccess is assured. An adrertisement in it introduces a book more directly and cleaply tban is possible iv any other way.

It obviously pays to advertise books when this can be done cfficiently aud economically. The first cost of printing a hook requires a Eale of from 500 to 1,000 copies to meet expenses. But after $a$ book is once printed, each sale yields a larger profit than is the case with ordinary commodities. Further each hook sold tends to sell others. It wonld be worth while to spend $\$ 2.50$ to sell a single copy of a $\$ 2.50$ book. A qnarter page advertisement in the Monthly, costing $\$ 2.50$ at page rates, conld scarcely fail to accomplish this. It might tend to the adoption of a textbook increasing its sales by hnndreds or thousands.

It is also true that, quite apart from commercial profits, an athor wants his book to be read and its pnblication known. There are very few scientific books whosc sales pay for the time spent on them. An author publishes because he wants to advance science and because it is part of the dnties of his position. It is consequently important, even apart from the effect on sales, that tlic pnblication of a book sbould he made known.

Publishers and authors do not seem to realize fully the advantages of advertising hooks that lave been published in preceding years. They may be as valualle as ever, but the sales become sulall, hecause the books are not bronght to the attention of those concerned. The proceeds of sales are clear profits and may lead to a ner edition. All new books should be advertised in The Popular Science Monthly as a matter of course, bnt it would also pay to advertise there many hooks other than those wbich have just been pnblished.

A mong the publishers who have advertised
THE POPULAR SCIENCE MONTHLY

The Monthly, now in its sixty-ninth volume, is one of the half dozen great American magazines; its circnlation is the largest of any jonrnal of its class; its charges for advertising are low. Thereare good jonrnals with lalf the circnlation of the Monthly which charge four times as much.

The Popular Science Mronthly has a very large lihrary circnlation, inclnding nearly all clnoational institutions; it is snlsscribed for or read by most of the scicntific men of this country and hy those having scientific interests; it las on its list a large percentage of mcn of wenlth and influence; it las a relatively large foreign circnlatiou.

The high standards that have always been naintained in the editorial pages of the Monthly must give weight and influence to tbe advertising pages. When a magazine is filled with fiction and sensational articles its advertisements are less likely to be trusted. Only advertisements of the highest class are accepted for the Monthly.

The advertising space in a magazine costing three dollars a year is worth more tban in cheaper magazines. The copies are likely to he read by a number of persons, to be preserved and bound.

At the ratcs cbarged The Popular Scicnce Monthly is one of the most desirnble mediums for all advertising of a bigb class. For special advertisements, appealing to the intelligent and well-to-do witb scientific iuterests, it is witbont a rival.

THE SCIENCE PRESS NEW YORK CITY: SUB-STATION 84 GARRISON, N. Y., AND LANCASTER, PA. 


\section{WORLD BOOK COMPANY, PUBLISHERS}

CASPAR W. HODGSON, MANAGER

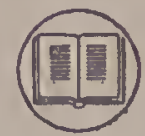

NEW YORK ADDRESS: PARK HILL, YONKERS, NEW YORK

TELEPHONE NUMBER: "I 5 I I YONKERS"

MANILA ADDRESS: POST-OFFICE BOX IIOO, MANILA

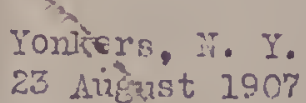

Dr. Figar A. Vearns

Post Surgeon

Fort Tatten

Long Island, I. Y.

:iy dear sir:

Captain äccoy has just written me from the Yosemete Valley telline of your roaming through :indanko and zindoro as a naturalist. I am makine a map of the Philimine Islands and am sending you a statement about it. I will also send you a blue print of iindanko and jincioro upon which I would like to have you rake corrections and additions as accurately as you can. I'.l工 promise you a complimentary copy of the map when it is done. If you will let me know at once whether you will be aviilable for this, I will forvard the print very promptiy.

I would like to get anything you do within a veek as I leave for lianila within two weeks and want all corrections made on the map before I go. It is now being engreved on stone.

CWH-IIH

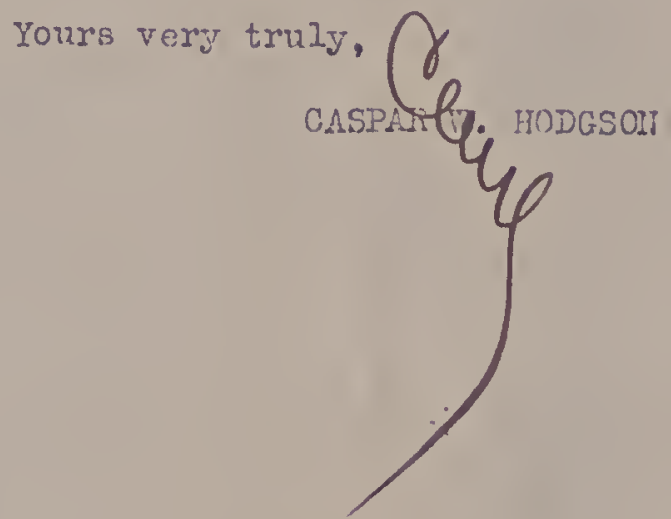


UNITED STATES NATIONAL MUSEUM

WASHINGTON

Sept .17.07.

Dear Dr. Means:

read to see you back a gain!

When shall we see you in the Bird Gallery?

A collection arrive here yesterday, ouch of which we received 8844 skims, but there is no sign of that Dr. Porter collection among them! I have reared 884 entries in our catalogue book for your bird, but if there are any more on the way 9 should like to know of it before I catalogue ann other material. Not any of te skins are labeled. So you expect to supper the labels, or sand on the register to na, po that we can write them? Wi have a large number of blank labels on hand for that purpose.

Hare not yet peen your descriptions of neut birds in the grum. of fie, but the grue 
no. is the last wa have received here. Sam interested to know what your new senuais. Io it the Edoliowona-like bird from Mindowas? T think that ia a now genus.

Suppose you incl be at home anyour birthday this year, but you need not let it interfere with dropping me a line instant h. Hope it will not take sweet or more after the event before you can hold a pen.

You will find come changes here: new secretary; or. Ralph dead (July 8); newbritding getting into shape; Ar, Ridgway in Lelinois, recovering form severus breakdown; miller in London; 5 new storage cares on Bite gallery, ste., ste. Bartach fore to Philippines on the 20<compat>. Wants to see you if he cam. Best wishes from Cwt. F Rile z.

Your rete.

alarwrichmond. 


\section{WORLD BOOK COMPANY, PUBLISHERS}

CASPAR IV. HODGSON, MANAGER



NEW YOKK ADDRESS: PARK HILL, YONKERS, NEW YORK

TELEPHONE NUMBIR: "I 5 II YONKERS"

MANILA ADDIRES: POST-OFFICE BOX IIOO, MANILA

Yonkers, New York. October 18, 1907.

Dr. Fidgar A. Ifearns,

Fort lotten

Long Island

New York

Dear Sir:

Captain F.R.NicCoy, who very kindly looked over part of the large map of tire Philippine Islands which tic World Book Company is issuing, mentioned you as a traveller and explorer well acquainted with various parts of the Philippines, and especially with lindanao. He suggested thatyou might be willing to look at a blue print of the map and correct any errors that you might find. A letter asking this favor of you was sent to you, but as no answer has ever been received, it is probable that the letter did not reach you.

inclosed is a print of Iindanao. If you can take the time to go over it, we shall be greatly indebted to you, and shall be glad to send you a copy of the map as soon as it is printed. We are sonewhat pressed for time, as the engraver is alm ost ready to begin on kindanao, and therefore request an early answer.

$I: / \mathrm{P}$

Yours truly, Caspar W/ HodEson. thas? 


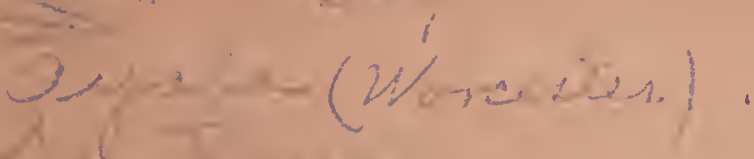

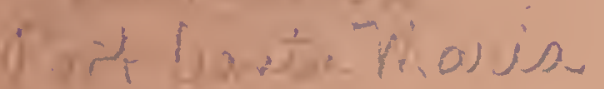

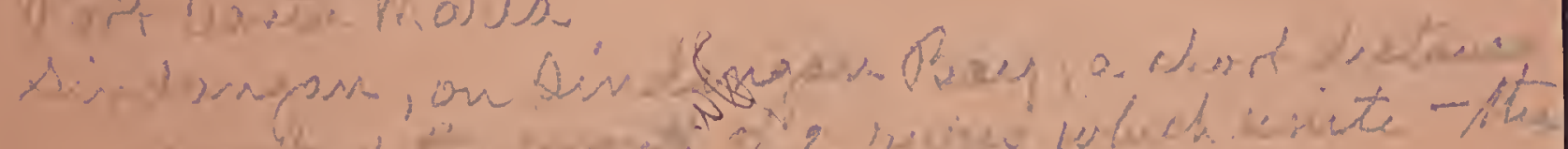
$\rightarrow$ Priul awe sisen.

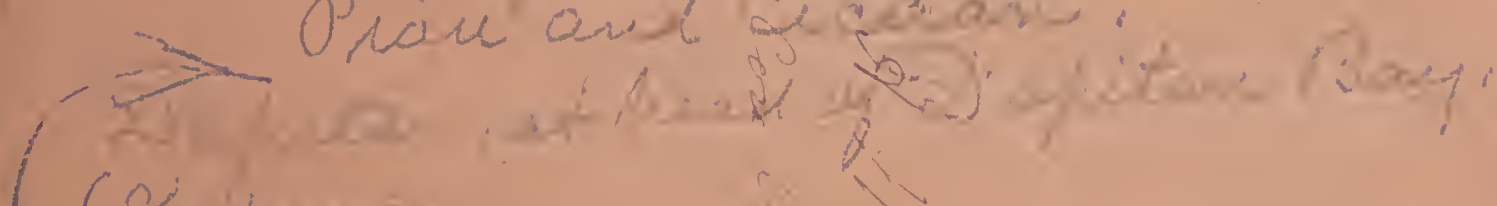

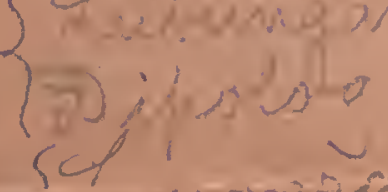
Bust





Jimitish

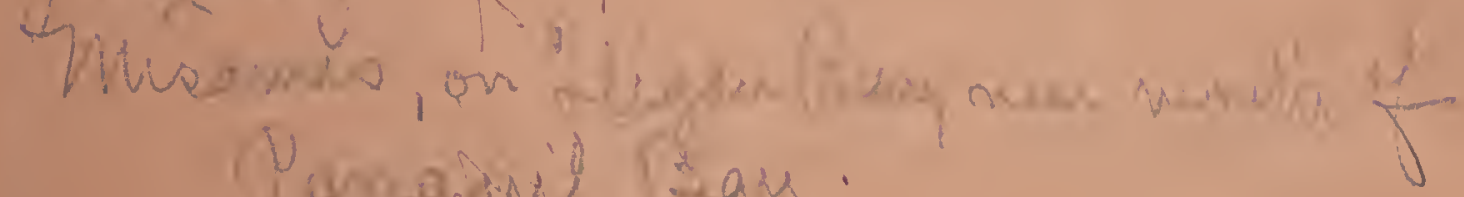
Namgawi. Sary.

Quertor $\}$ in kegan Vay.

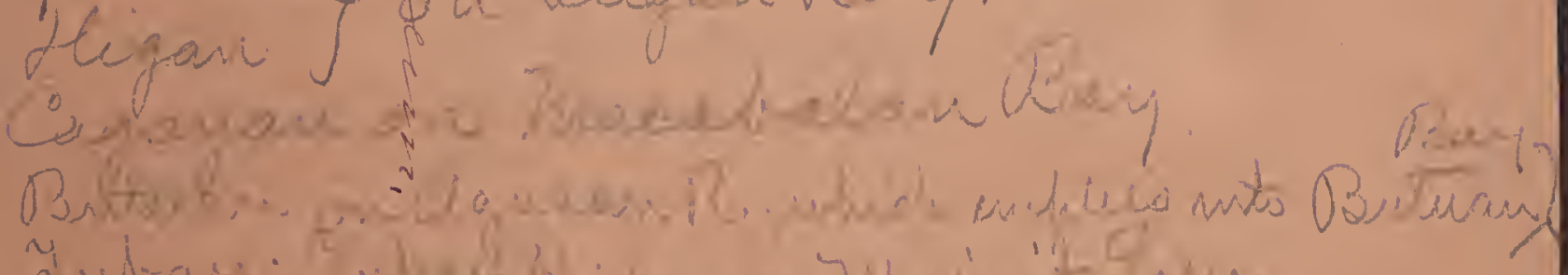

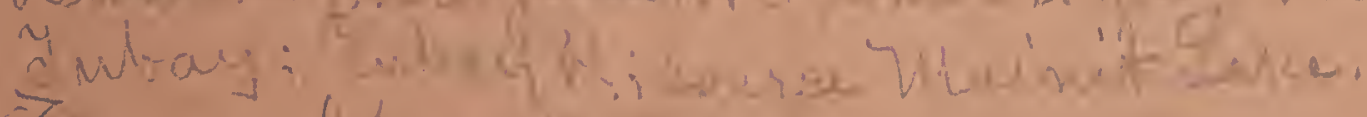

(3)

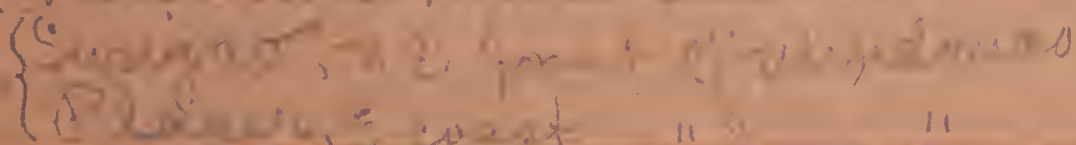


tears. As

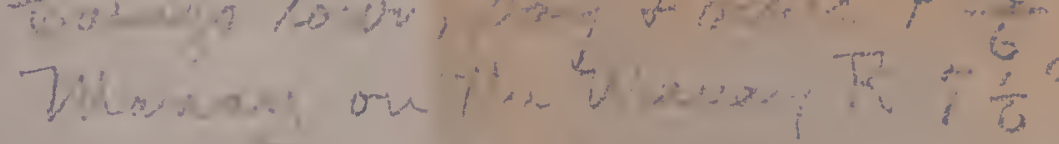

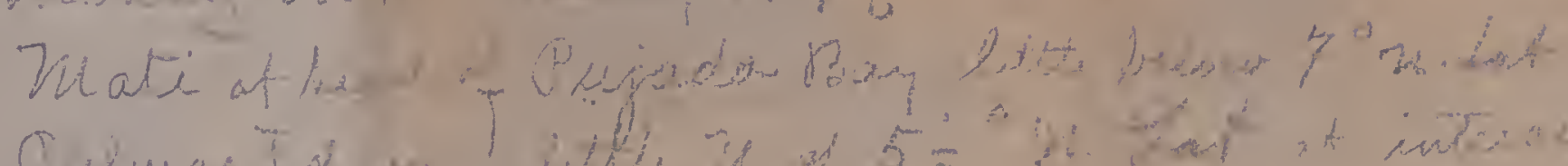

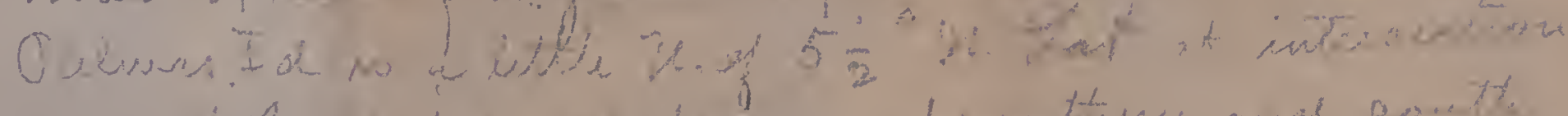

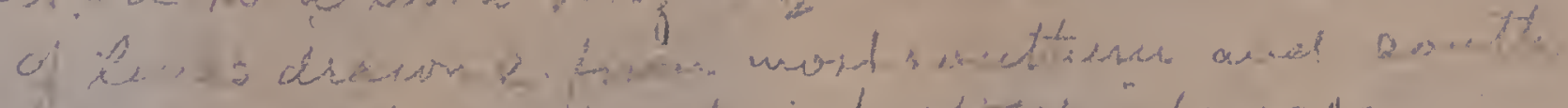

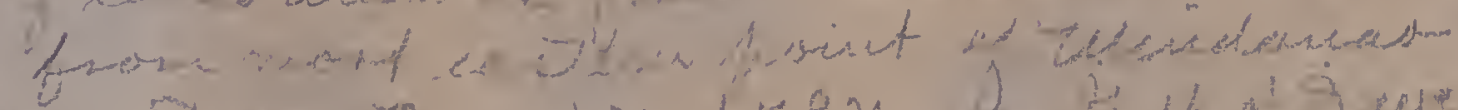

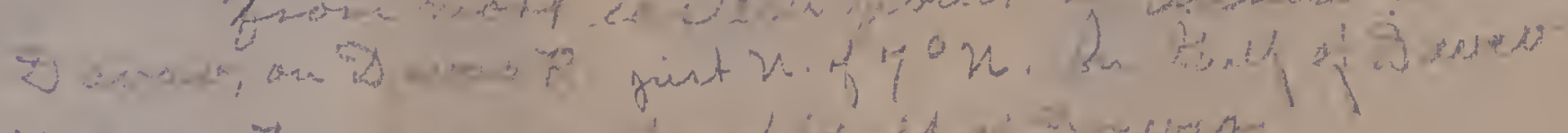

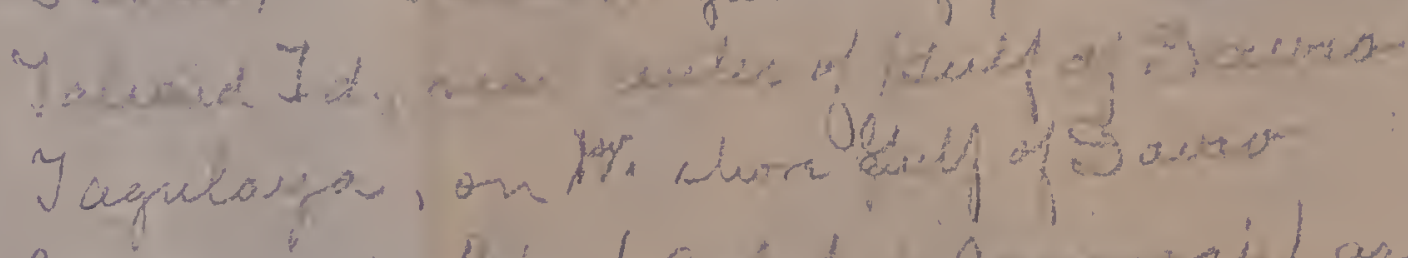

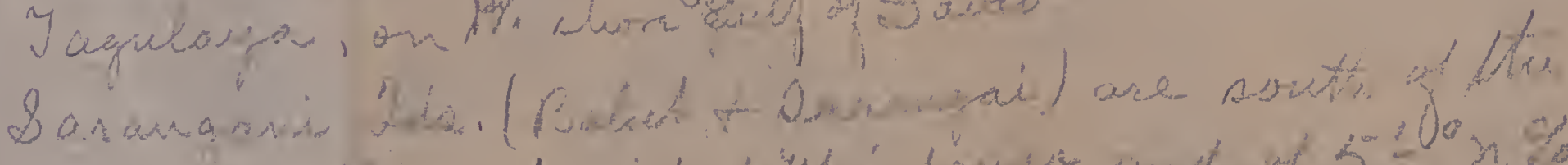

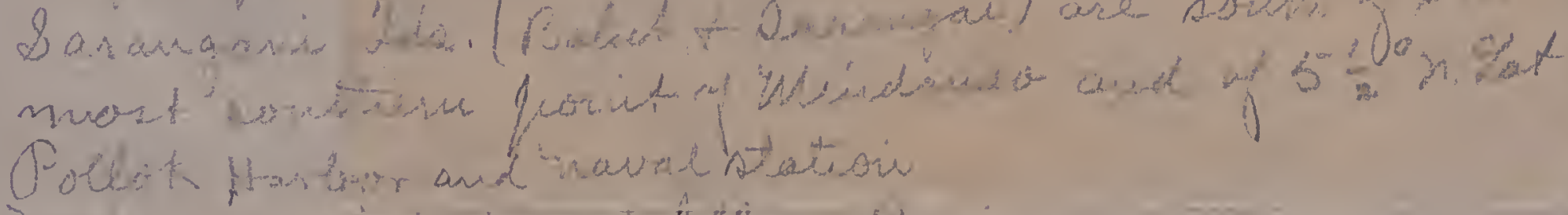


Eareuncent at mead of " is"

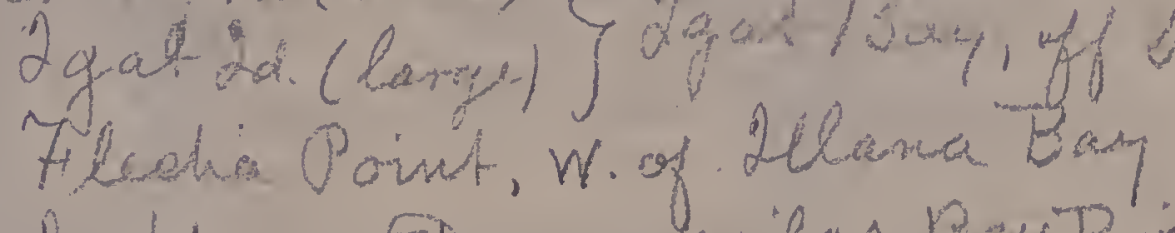

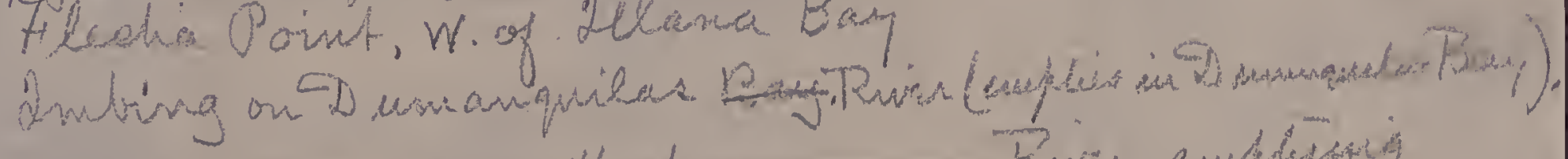
Q

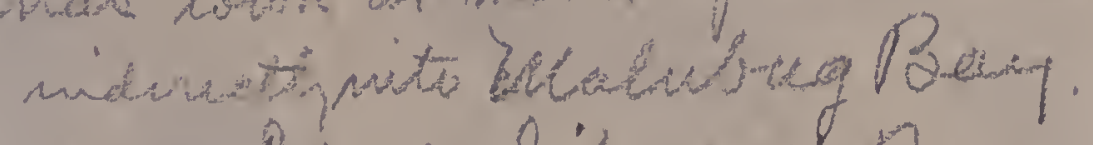
Rusis, eswiplyatis

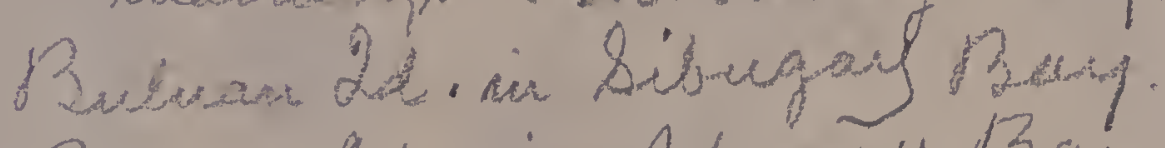

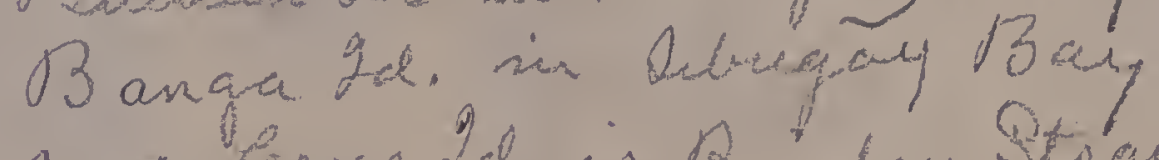

Landateriez 2el, in Basilan Btrait

Ister do

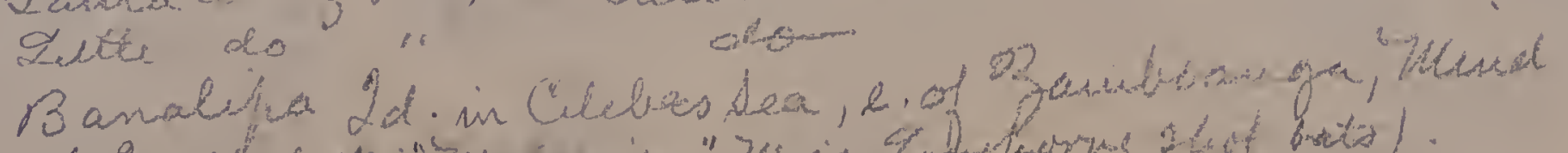

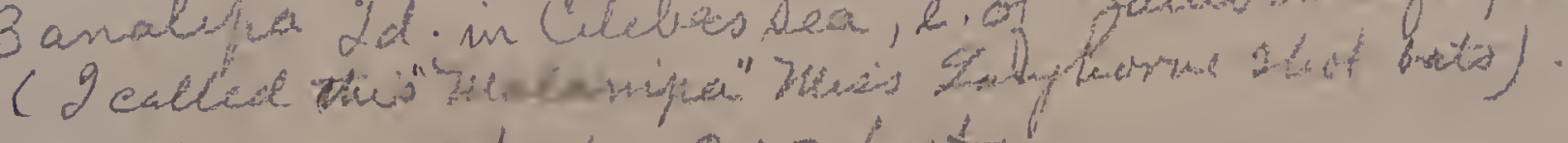

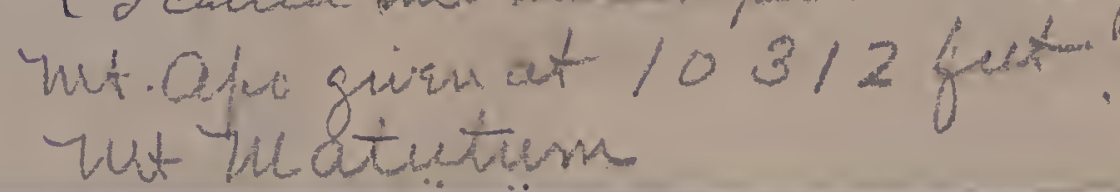




\section{WORLD BOOK COMPANY, PUBLISHERS}

CASPAR IV. HOIDGSON, MANAGER

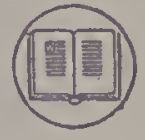

NEW YORK ADDRESS: PARK HILL, YONKFRS, NEW YORK

TELEI'HONE NUMBER: " I5II YONKERS"

MANILA ADDRESS: POST OFFICE BOX IIOO, MANILA

Yonkors, I. Y.

29 october 1907

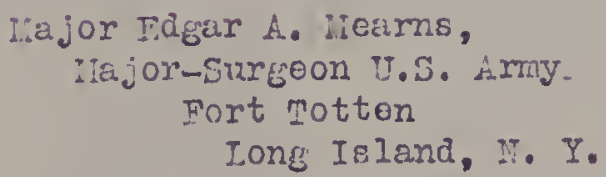

Dear Sir:

We have recelved the two packages of blue prints and the information regardint the mar for which we thank you. Our engraver is at present at work putting the map on stones and we should be very glad to have you come here somotime very soon and sec what we have been doine. The encraver is workine right here in the shop. lirs. Hodeson extenis an invitation to you to spend a did or at least a pert of a day with us.

You can find our place by takine the subway to Kineshriage and there transforring to the trolley which will take you to the Fark Hill Railroad station where you leave the car and climb the hill. If you will inquire at the elevator at the foot of the hill, you vill be able to find us. We holje that wo may be favored with a visit from you. 
SMITHSONIAN INSTITUTION

UNITED STATES NATIONAL MUSEUM

WASHINGTON, D. C.

nor $20,1907$.

Dear or.mearus:

Srecaired your later of Oct. 30, with list of 61 skins you had left at manila. but the other list of bird left wot me egregor promised by you "in a geum donga" hes not yet arrived! Neither has the lick from me Seeger come. I meas it, as 9 hare reached a point where o much eliminate all the known numbers from your register in order to fix serackel skim that cane in pistons any numbers or other means of identification. If 9 could check off. for instance, every specimen of Cimmpria whitehead, scored then tee the berra (and write label) for two skins (an ad. t + in. s) which have no tags.

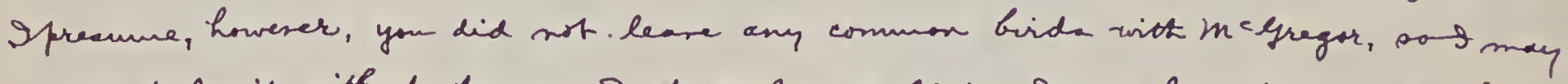
be able to do it without the use of the melgregor lint. I may have to wait for the

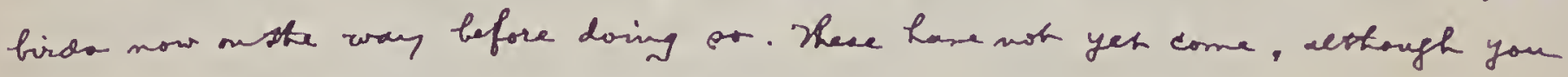

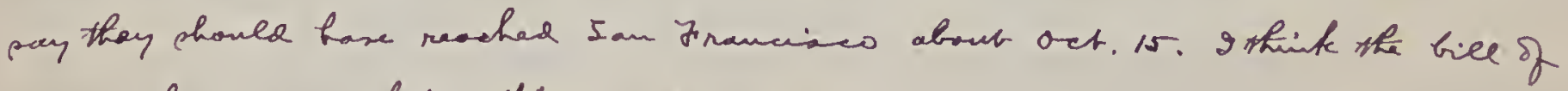
lading her come, but nothing more as yet.

The anil attend to the matter of Palawan china from major white. Were the bird china already raceirad collected by him ot his booster? I believe you paid then showed be credited to him, and an acknowledgment pent to him.

How about the schroder birds? are they tote credited to him or to you, and if to

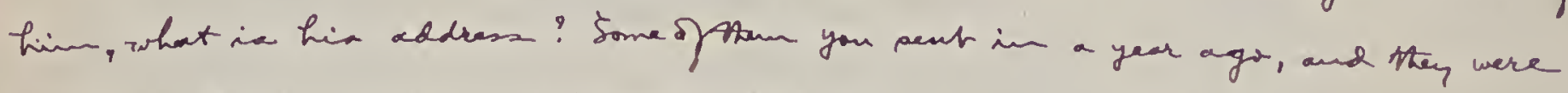
catalogued along with your (under numbers only), and it will be a job to cancel those numbers and get them altogether, but 9 can do it if necessary. I have finished labeling all but the schroder and white birds, and will take them up ar soon as I learn from yon to whom 9 shale credit them. 
9 forgot mention when You were here that Haters described a

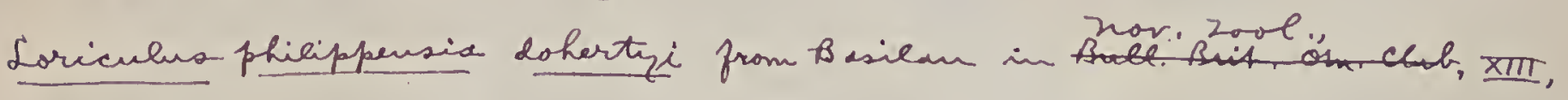
no. 4, Aec .22,1906, 757 .

Maned you like, to have me prepare a new register for you, numbering it ( for where you left of in the last one) wist our automatic numbering machine?

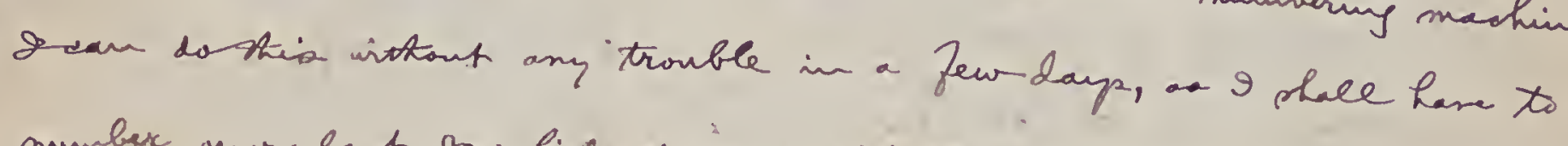
number c your last gao bikes or more sit te it in a few day pa.

Verytruez.

oharwichuord.

ort'́ curator, Din Birds. 
SMITHSONIAN INSTITUTION

UNITED STATES NATIONAL MUSEUM

WASHINGTON, D. C.

nov. 27. 1707 .

Tar Es. Marta:

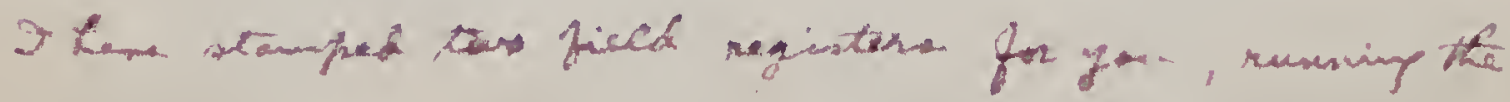

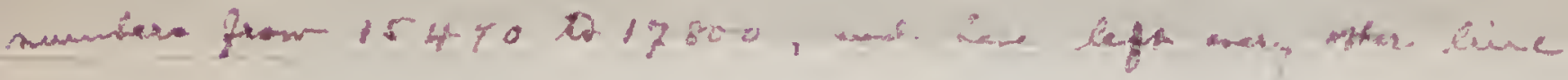

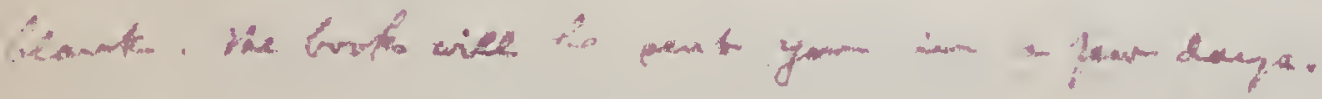

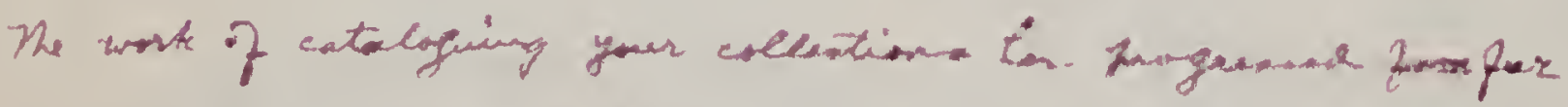

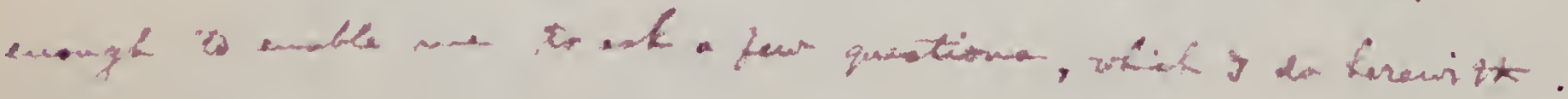

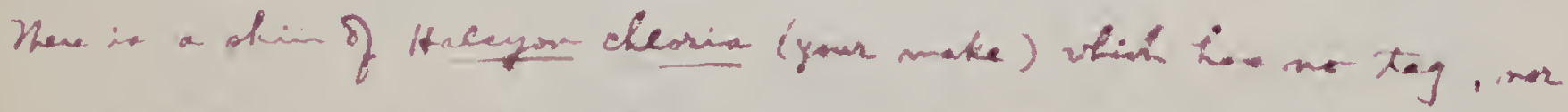



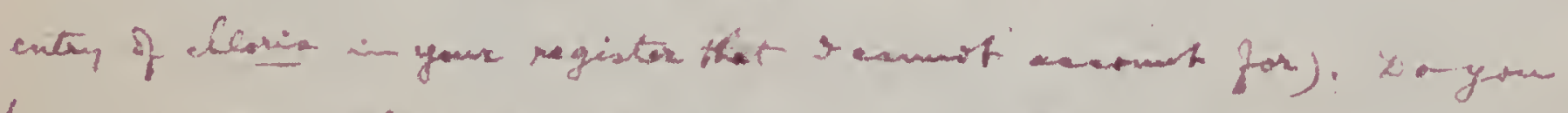



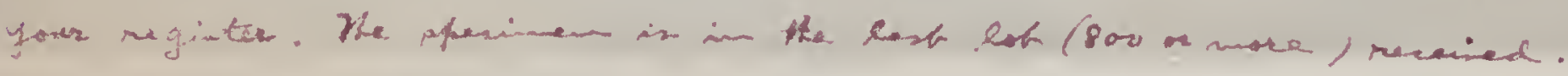

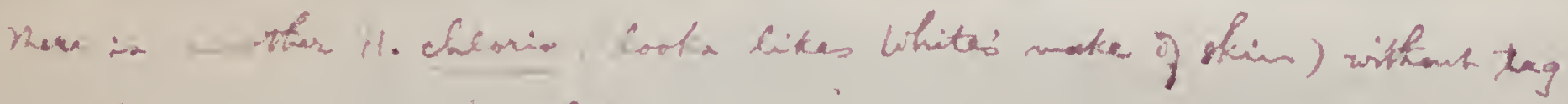

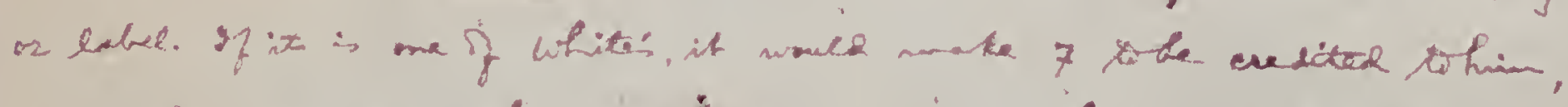

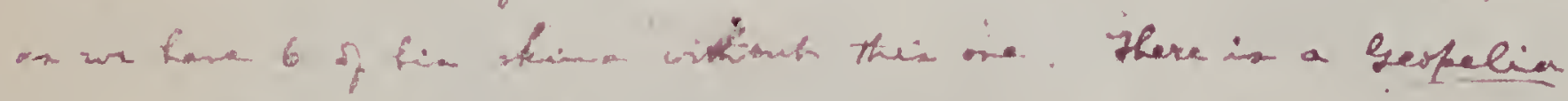



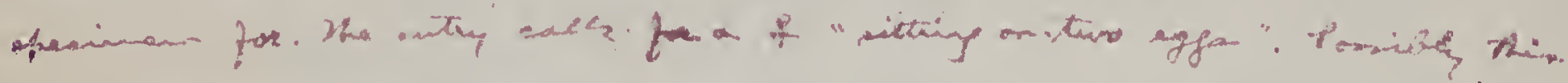

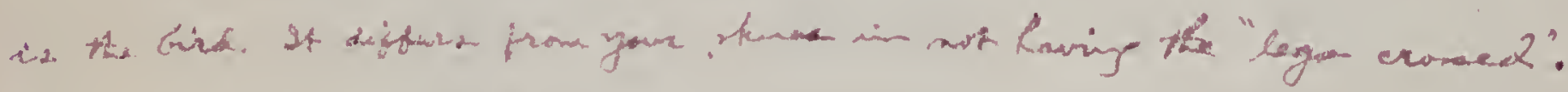
D. you reacongingen it? 


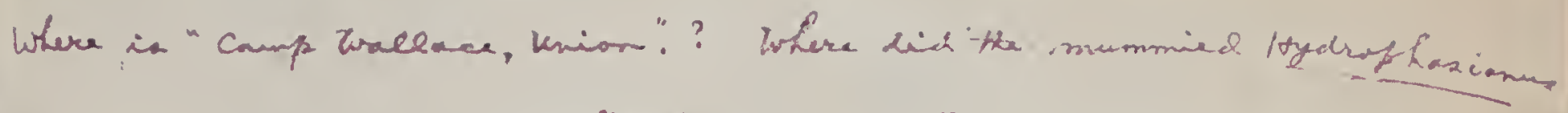
cone from? Is your mew Plifilura called. Litahineoni or schoderi?

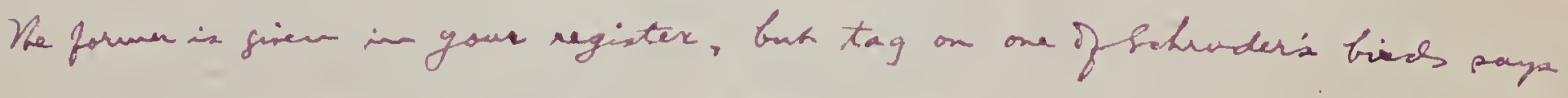

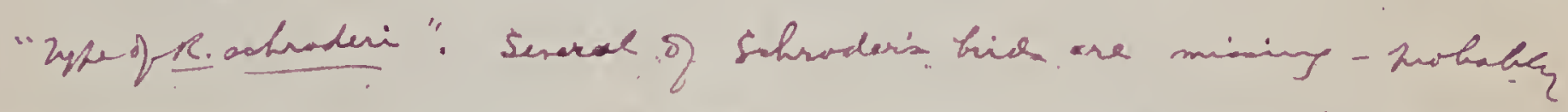

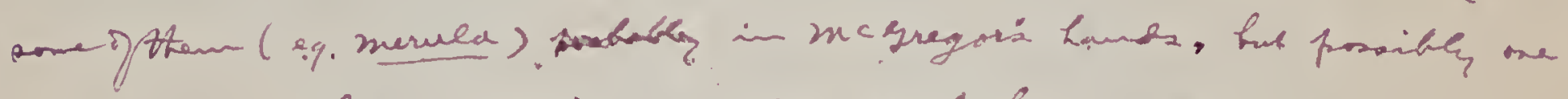

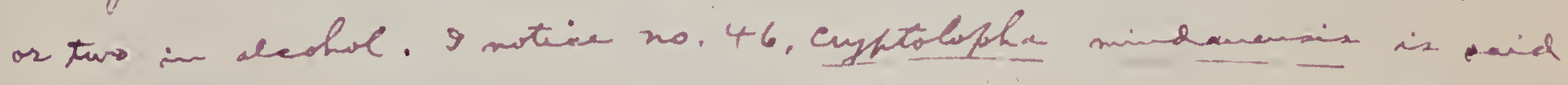

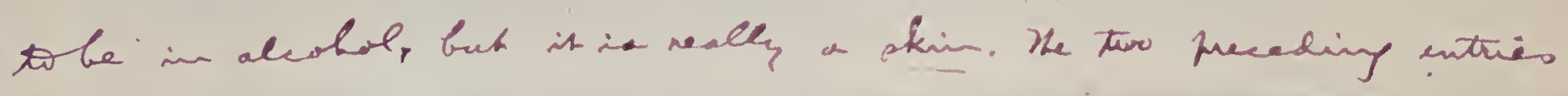

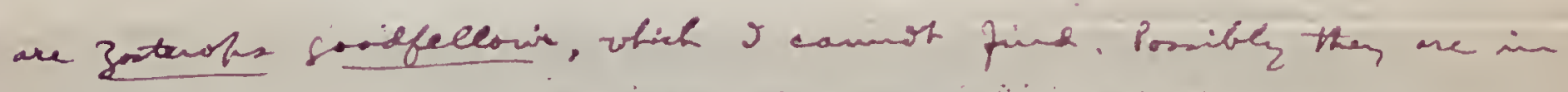

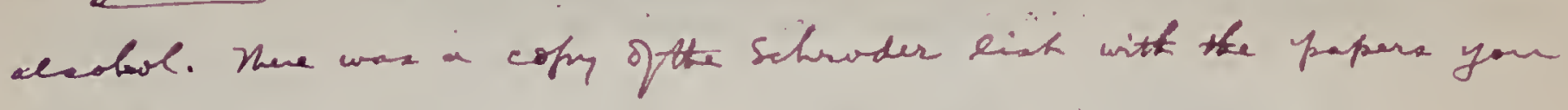
left here, so it wile not be mearsary to send a erfyy. Iras it no. 14279 (Strike) ot no 14280 (hombre) that was

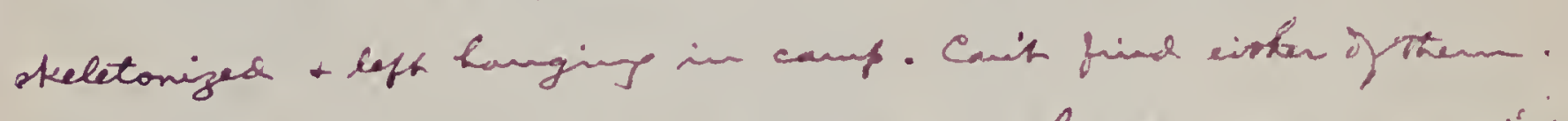
There is a Eanoshimes with tag no. 14115, bus the is anton in register

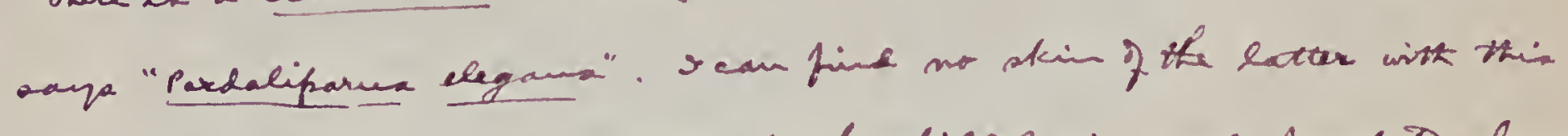


the entry. Do you recollect anything about is ?

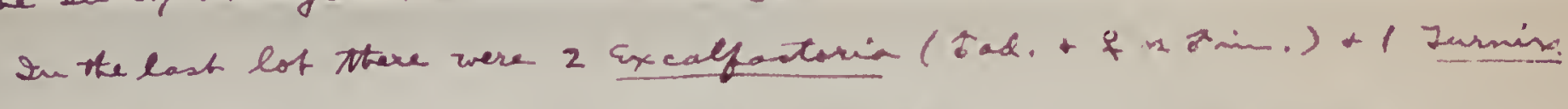


Erecalfatonia (n o.1529). Sad.). Sa you know any thing about them ?

I has checked of in your registers emery bird resined, and

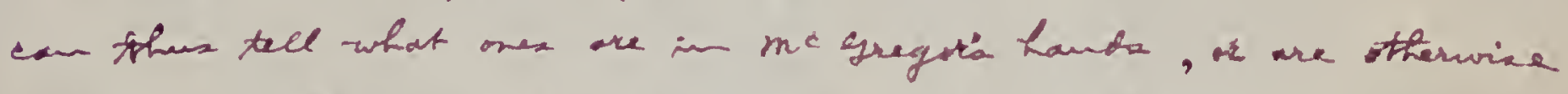
missing, but the questions above relate to the pew 9 cannot seated without your beef.

I notice on enter y in your regina of an "artamides" from 


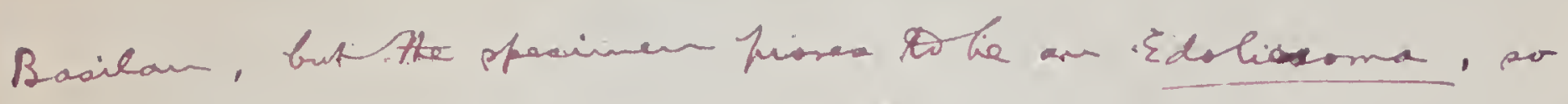
you are fortunate in having tho of thin i.

Then you reply to the above queries's may send a few move, but stains the bice are nearly straights now. I hame made

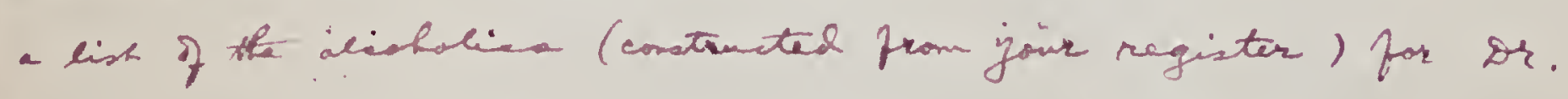
True. What is a Cagurang:? I Rave made out meme. of. for the schrode and white specimens, and will pee that the proper sokmowledganents are cent them.

If you go the pliliftines a gain it might not be a bad plan


paper, so you cone hare thin for use in eating up for tags. Set ma know before you go on another collecting condition.

Share asked obihtolsen to pent you the papers asked for.

$$
\begin{aligned}
& \text { Verptring." } \\
& \text { Aluritrichumen. }
\end{aligned}
$$

actsoniton, Dir Bris. 


\section{WORLD BOOK COMPANY, PUBLISHERS}

CASPAR W. HODGSON, MANAGER

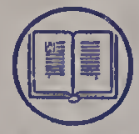

NEW YORK ADDRESS: YONKERS-ON-HUDSON, NEW YORK

TELEPHONE NUMBER: "I 5 II YONKERS"

MANILA ADDRESS: POST-OFFICE BOX IIOO, MANILA

Yonkers, N. Y.

30 November 1907

Viejor Eagar $\Lambda$. Hearns,
Fort Totten

N. Y.

Dear Sir:

We are returning under another cover the blue print which you so kindiy sent us, and thank you for this favor. We were very much disappointed in not having you call on us. The stone on which Mindanao is engraved has gone to the 11thographers.

Thanking you for your interest in our map,

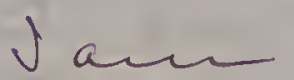

Very trily yours,

CASPAR T. HODGSON

OSR-MLA

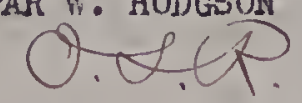


SMITHSONIAN INSTITUTION

UNITED STATES NATIONAL MUSEUM

WASHINGTON, D. C.

Summary $4 \sim 1908$

Lear Doctor Means.

I have today card-eatalogued the

three basteito you sent me in your last eat. The Malaysians to not excel the Indian women in fine workmanshiff; but their basketry has fur greater differentiation in stuecturab pasto. The ald piece has tithe tory all rights; int there is added a footing of rattan that would take the use of this page to describe. Add the coonderfue brainwork on the sides ane arouse?

Tho top, and you have a daisy. The hast bassets, - Looking so plain, is "1rexagonal weave ore lattes probation." "The fill te model carrying baskets, with a punily modern air and its clove titis is in place of rat Malay knots, has an oruminal wrap about the forbes of the bottom. 


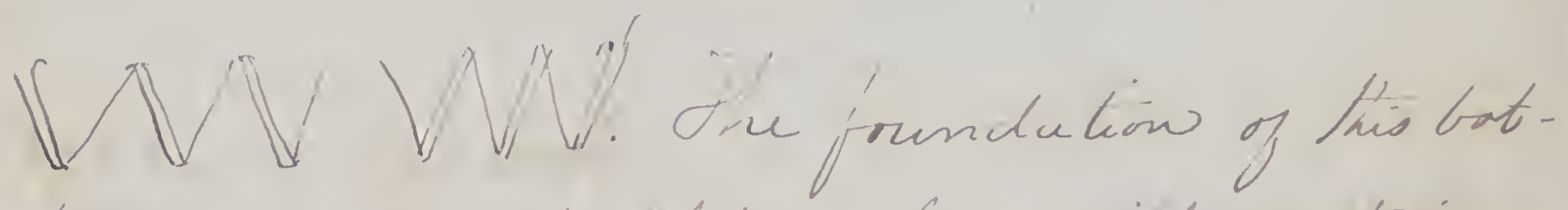
tom could not be pluiner. You wili see ct in ivery countric yart, by tho name of tatlico. Wel?, the outer row about the four sicles is corappes with zattan. A turnuma a hay is tio unit- Jown-funvarsicif-buckuarist town-forwans; or up

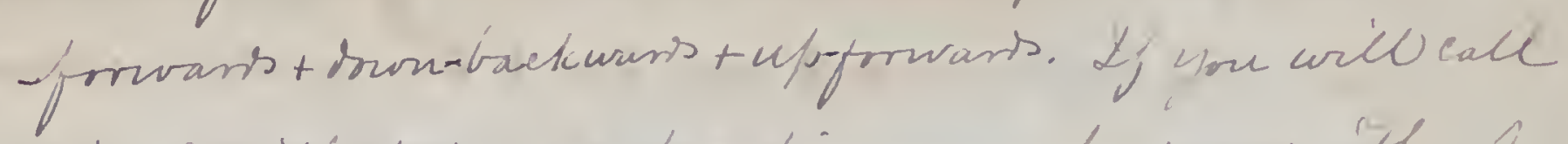

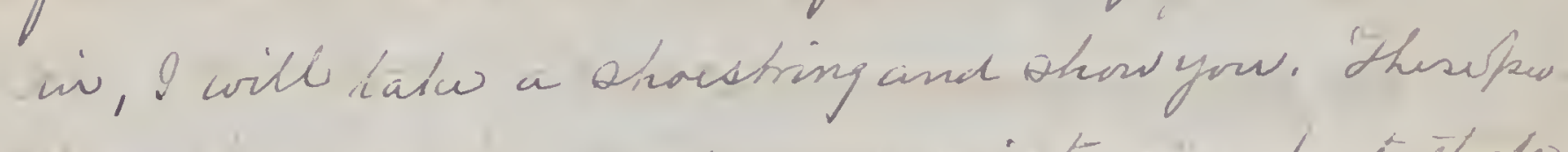

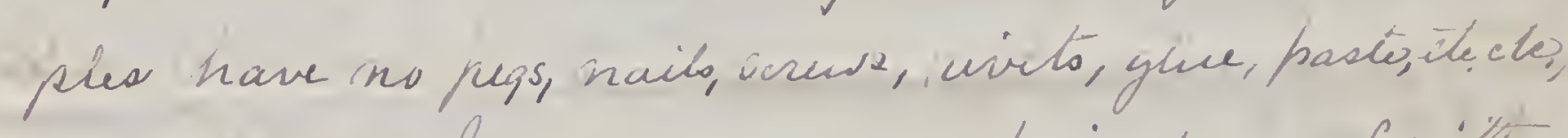
only Fnoto. I am ares, much impresser with your discriminating jestyments in seceting pecinens for orve. The thic titte pieces show an awful int of versatilit aming thoso hrove iaces. Bys the win, tho fine aid pieco is like thelchizedety, it-has cno locatity nor tribe onit. He wists you a year of heatth and properity,

Yours wincerely

C.T, hiasons 
SMITHSONIAN INSTITUTION

UNITED STATES NATIONAL MUSEUM,

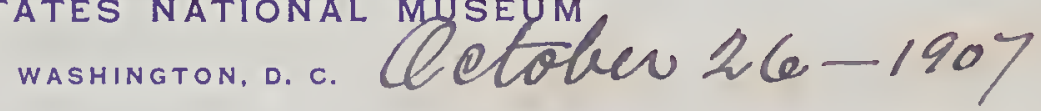

motor E. A. Means, Wee ts

Care o War slept - Nashimionu, Ml,

Lear Doctor Means.

lias sorry to miss you yester-

day, but doctor doe tells me that you

will be near. Your generosity to my Llefartments and your intelligent s selection of specimens have made me happy and I wanted to tell you so. Scan make out ethology, structure, and technic pretty well, but shall be glad to have a word from you now and then about materials. I a mo ending you a paper on one of your beauties.

Yours sincerely

O), Mason 


\section{SMITHSONIAN INSTITUTION}

UNITED STATES NATIONAL MUSEUM

W.ASHINGTON, D. C.

October 3, 1907 .

Dear Doctor Mearns:

With your last collection of delightful baskets is a little one, 8 inches long and three inches vide, that might have been made to hold pens and things on a desk. It looks as though it were made of the "bane pitr" used in our day for all sorts of things---baby carriages, tables, baskets, and the like. But the end of each separate stem has a little hole in it, as though it belonged to the exogens; so, I have to give up my rattan theory and fall back on the interrogation point. Do you know someone who can tell me the meterial of which this dainty little wicker basket is made? It is a great help to us to get possession of the name of the material,---both the English and the native.

With kindest regards and best wishes, I am, Very truly yours,

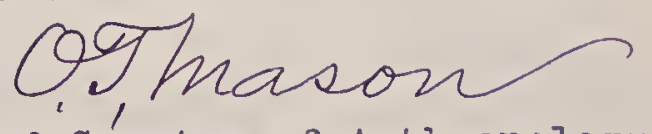


SMITHSONIAN INSTITUTION

UNITED STATES NATIONAL MUSEUM

WASHINGTON, D. C.

OFFICE OF

ASSISTANT SECRETARY,

$\tan 10,1908$

Dear Li. rearms:

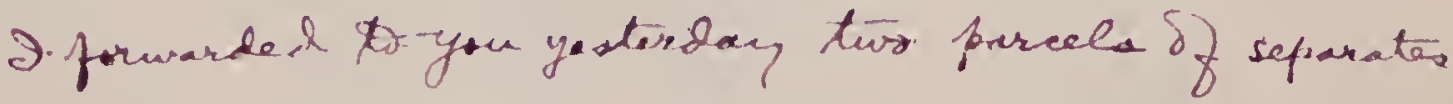
of your paper from the "Philippine Journal of Science" and toot the liberty of holding a third procter batch of spies here for was in labeling your tigpas,"t.. If you wite give me a biak of bf e mon to which you wish espies sur t, I shale be glad to distribute the copies us for as they will go (there 23 copra here).

I have labeled your types, recept malinda angina magregori, which pears to be stile in manila.



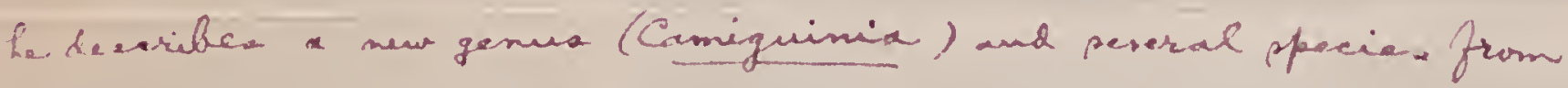

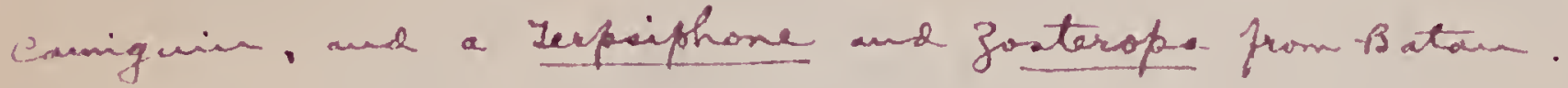

Verztrulz. chorewrichuend.

Ait curator, DirßBirs. 
SMITHSONIAN INSTITUTION

UNITED STATES NATIONAL MUSEUM

WASHINGTON, D. C.

$7 a n \cdot 11.1908$

Dear Pr. Meatus:-

O) an ven much obliges for your letter of Jan gs, enclosing one frow Mr. M. D. Merritt. We will look out for the Tamara and 9 an making requires also about other things - As soon as I fris out what h it is bust bask for. Icel have 1 letter inter lo $\mathrm{Mm}$. Brevity:

the hat a request y exterday form Cups. I. R. In C Coy at the White Arouse for copies of sour paper on Philippine manuals, one copy being intended for the President. The matter was taken up immedialets un d Ipresume the President has his copy in haunt be this trine.

to prig you aw well. $9 \mathrm{~cm}$ with turtreqaus fours var tu cere? Main E. A. Meatus Cl. ta. Fort Jotter , on. Y. 


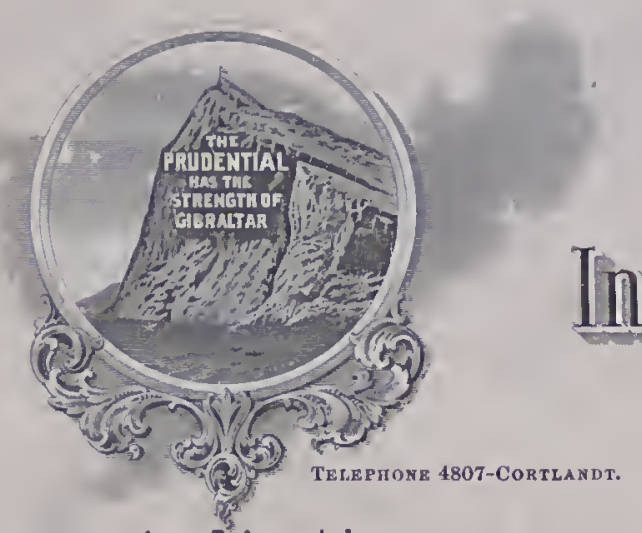

IN RE Application.

LESLIE D.WARO, VIC OH F. DRYOEN, President.

EDWARD GRAY, Secretary.
GEORGE B. SPEER, Supervisor Ordinary Agencies.

The Prudential Insurance Company of America.

Home Office. Newark .N.J.

WILLIAM DUTCHER, MANAGer,

ORDINARY DEPARTMENT,
ROOMS 10O3-10O7, 141 BROADWAY,

NEW YORK CITY

Jan. 16, 1908.

My dear Major Learns:

I enclose to you herewith application of $\mathrm{J} . \mathrm{H}$.

Wetherholt of your post. Will you please canine him, and send the papers to me at your convenience?

NM

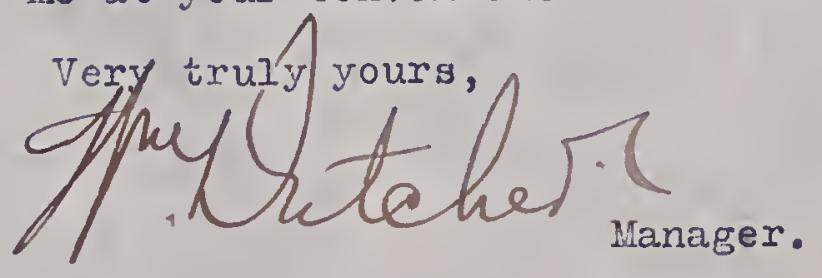

To

Maj. E. A. Means,

Surg. U. S. A.

Fort rotten, N. Y.

I has a letter from Basil a fur days since; he is looking ford to the tune when he can foin his family- I hope yon taine al ing horseback ride daily. 


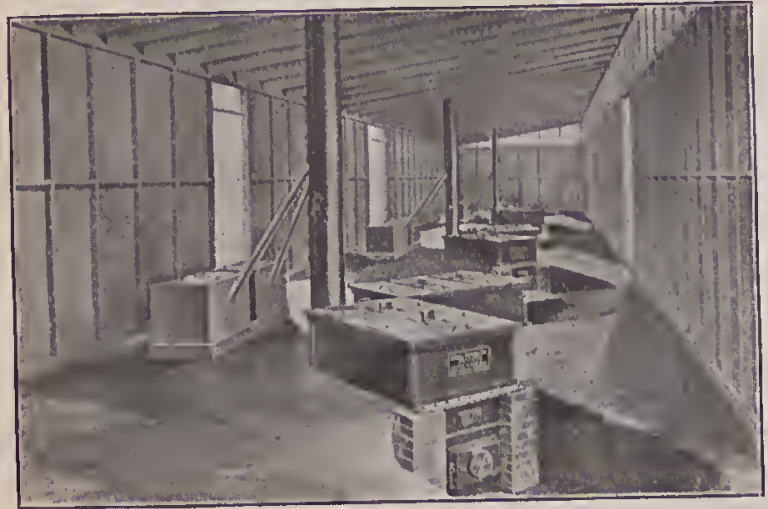

The McCall Incinerators, as in usc at the Jamestown Exposition

\section{MCCALL INCINERATOR}

\author{
JAMES H. MCCALL \\ PATENTEE, OWNER ANO MANUTACTURER
}

HUNTINGDON, TENN., U. S. A. JUIY 31, 1908.

Waj. Edgar A. Hearns, Wodical Corps, Fort Totton, N. Y.

Dear Sir:

I have the lonor to renort that I have made a very ir.portant inmrovement in the construction of the HcCall Incinerator. This imrovement consints of a sheet steel fire box which is lined with a fire proof material, thus obviating the use of brick and the necessity of emloyine skilled lahor in setting up the machines, thereby reducing, to a considerailo extent, the cost of installetion.

The locall Incinerator originally had this sheet steel fire box, but for carms of more or less nermanency brick vore found to be rore dosirable. The only objection to the sheet stoel firo box was that it would warp under intense heat, but in tho imrroved pattern this is obviatod by the use of an asbestos lining.

With this improvement the machine can be installod in about one-trird of the time required when brick are used, and, in my opinion, will be practicable for use rith movine troops, as thoy can be readily loacied on an oscort vagon, ambulance or other transportation.

The fire box is constructod so the suporatructuro vill set unon it without alteration of the other parts of the incinerators. Therefore all of the incinerators nov in use by the Government (about 500) can be converted into mobilo machines by supplying two fire boxes for each machine, which can bo furnishea at a nominal cost.

The use of brick is all right for permanent carnos, tarcet raness, otc., but I am quito suro the sheot steol firo box will be preforablo for maneuver camps, or movine troons.

A demonstration of the advantases of this improvement vill be made at the Waneuver Carp, Fort Benjamin Harrison, Indiana in sentembor next.

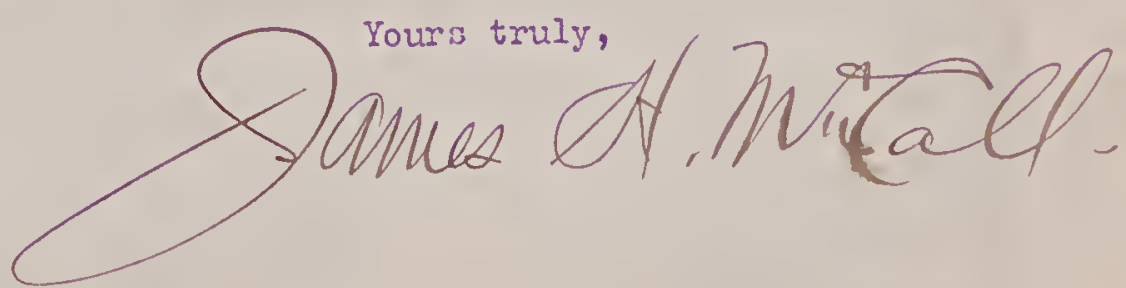


$184 V_{s}$ qur. Yronhiaglare, 0.6.

$$
\text { Aug } 35908
$$

Angozar huior:

'Mift Rearn?

lattor caven this mosuing ans Shashin to cok Jun to Cunch with m Q wing jour sxaminathion in SafkMan will ter gare to go and come wh will and wr will ny to fwinith sufficiench mutrinesuh to enable yor to indure the trial. Mre had leve Ebesh and the hustije of his encerp anm ais gres Lincaral fims himing Esolerp 




The Postal Telegraph-Cable Company (Incorporated) transmits and delivers this messagel subject ko the terms and conditions. printed on the back of this blant.

Received at Postal Telegraph Building, 1345 Pennsylvania Ave., Washington, D. C. Telephones: Mal o6oo 26Di Ho. 210P 43-pd Govt Fnt Di.

Governors-Island NY sept 28-08

Major Edgar A Mearns,

Medical Corps, Care Surgeon General,

( 1841 V Street $N-T$, ) Washn D-C.

Talking test ordered by special orders two twenty one these

headquarters postponed your case you will be notified later wher

to take test acknomledge. By command Major General Grant.

Heistand, Adjt Genl. 


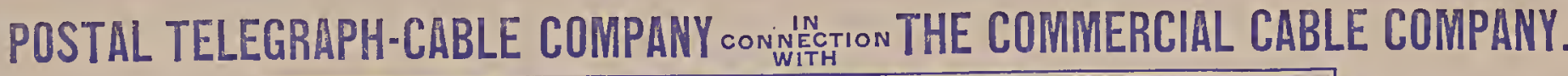

THE WORLD'S

Greatest Telegraph AND GABLE SYSTEH.

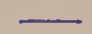

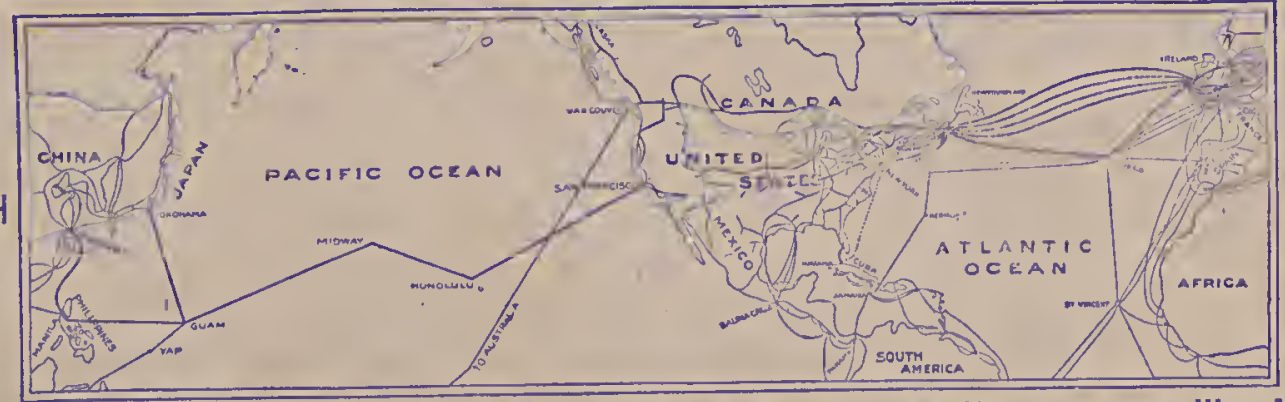

EXTENDS OVERTWO-THIRDS AROUMD THE GLOBE.

The Greatest Telegraph ahd Gable System in the World. Extends Over Two-Thirds of the Way Around the Earth.

\section{THE POSTAL TELEGRAPH - CABLE COMPANY (INCORPORATED)}

TRANSMITS AND DELIVERS THE WITHIN MESSAGE SUBJECT TO THE FOLLOWING TERMS AND CONDITIONS:

TRANSMITS AND DELIV ngainst mistakes or dclays, the sender of a messege should order it REPEATED; that is, telcgraplied back to the originating office for com. parison. For this, one-half the regular rate' is charged in addition. It is agreed letween the sender of the incssagc tre or for non-delivery, of any UNREPEATED Telegraph-Cable Company, that said Company shall not be liable for mistakes or delay's in the transinission or delivery, or for for non-delivery, of any REPEATED message, beyond the amount rcccived for sending the same; nor for mistakes or dclays in the transmission or dclivery, or for non aluavoidable interruntion in message beyond fifty times the sum received for sending the samc, unless specially ansured, nor in any case for delays arising irom anavoitable intertaptoriat the working of its lincs, or for errors in cipher or obscure messages. And this Cnmpany is hereby made the agent of the sender, without liabilts, to fortar

any message over the lines of any other Company when necessary to reach its destination. rist. Correctness in the transmission of messages to any point in addition to the usual clarge for repeatcd messages, viz.: one per cent. for any distance no

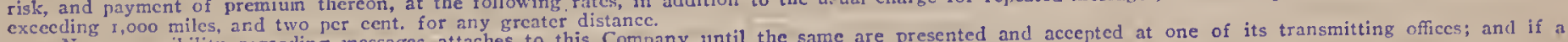
No responsibility regarding incssages attaches to this Company until the same are presented and accepted al one

message is sent to such office by one of this Company's messengers, he acts for that purpose as the agent of thivery at a greater distance a special charge will Mlessages will be delivered free within

lie made to cover the cost of such delivery.

This Company will not be liable for damages or statutory penalties in any ease where the claim is not presented in writing within sixty days after the

message is filed with the Company for transmission. repeating a inessage back to the sending station for comparison.

The hinding upon the receiver as well as the sender of this message.

No employec of this Company is autlorized to vary the foregoing.

CLARENCE H. MACKAY, PRESIOENT

CHARLE'\$ C. ADAMS, SECONO VICE-PREST. EDWARD J. NALLY, VICE-PREST. AND GENERAL MANAGER 
HEADQUARTERS DEPARTMENT OF THE EAST,

$\left.\begin{array}{c}\text { Special Orders, } \\ \text { No. 221. }\end{array}\right\}$

*
Governors Island, New York City,

Septem ber 21, 1908.

[EXTRACT.]

$*$

$*$

$*$

3...In compliance with the provisions of General Orders, No. 79, War Department, May 14, 1908, the following-named officers, liaving stated their prefcrence for the walking test prescribed in paragraph 4, of the order mentioned, will assemble at the places indicated below for the purpose of undcrgoing the physical examination and test.

The senior officer of cach group taking this test will be held $1 \mathrm{e}$ sponsible that all conditions of the test arc strietly obscrved by every officer in the group, and he will follow the route subinitted by the artillery district commander and approved by the department com. mander.

At the conclusion of the test the senior officer of each group will submit a detailed report, stating thercin the names of the officers participating, the ronte taken, the distance traveled ench day and the hours of beginning and ending the daily march; together with a certificate that the provisions of General Orders, No. 79, War Department, 1908, have been carried out, or, in case of failure by any officer, the circumstanccs attending such failure.

The physical examnination of the officers named will take place October 4,1908 , at the posts where they assemble and will be conducted by the medical officers designated below.

The physieal test will be conducted October 5, 6, and 7, 1908.

The uniform to be worn is field dress, consisting of campaign hat, scrvice or khaki coat and breeches with lcggings and russet leather shocs.

Within threc hours after eompletion of the third day's walk, each officer taking the test will again be examined by the medical officers.

A supply of blank forms (No. 377, A. G. O.), on which the physical cxamination should be reported, will be furnished the senior medical officer who has bcen designated to examine each group by the Adjutant General of the Department. These forms should be carefully filled out and completed in every respect beforc they are forwardcd to department headquarters:

AT FORT 11. G. WRIGIT, N. Y.

Coloncl Charles D. Parkhurst, Coast Artillery Corps, Fort H. G. Wright, N. Y.;

Colonel Frank Baker, Ordnance Department, Springfield, Mass. ;

Major Wilmot E. Ellis, Coast Artillery Corps, Fort Terry, N. Y.;

Major William C. Davis, Coast Artillery Corps, Fort Adams, R. I.

A medical board of officers to consist of: 
Captain Allie W. Williams, Mcdical Corps, Fort H. G. Wright, N. Y.;

Captain IIarry G. IIumphreys, Medical Corps, Fort H. G. Wright, N. Y.,

will conduct the physical examination.

AT FORT IIANCOCK, N. J.

Coloncl Henry L. Harris, Coast Artillery Corps, Fort Hancock, N. J.;

Lieutenant Coloncl Clurence Deems, Coast Artillery Corps, Fort Haneock, N. J. :

Major George F. Barney, Const Artillery Corps, Fort Hancock, N. J.;

Iajor Charles C. Jamieson, Ordnanec Department, Watervlict Arsenal, N. Y.

A medical board of officers to consist of:

Captain William $M$. Roberts, Medical Corps, Fort Haneock, N.J.

First Lieutenant Arthur R. Jarrett, Medical Reserve Corps, Fort

Hamilton, N. Y.,

will conduct tho physical examination.

AT FORT DUPONT, DLL.

Colonel John R. Williams, Coast Artillery Corps, Fort DuPont, Del. ;

Major Charles A. Bennett, Coast Artillery Corps, Fort Mott, N. J.

A medical board of officers to consist of :

Gaptain Henry D. Snyder, Medical Corps, Fort McHenry, Md.;

First Lieutenant W. Church Griswold, Medical Reserve Corps, Fort DuPont, Del.,

will conduct the physical examination.

AT FORT HOWARD, MD.

Licutenant Colonel William C. Rafferty, Coast Artillery Corps, Fort Howard, Md. :

Major Elmer W. Hubbard, Coast Artillery Corps, Fort MeHenry, Md.

A medical board of officers to consist of:

Captain Charles F. Morse, Medical Corps, Fort Howard, Md, ;

First Lientenant William L. IIart, Medical Reserve Corps, Washington Barracks, D. C.,

will eonduct the physieal examination.

AT FORT MONROE, VA.

Coloncl William II. Coffin, Coast Artillery Corps, Fort Washington, Md.;

Major Thomas Ridgway, Coast Artillcry Corps, Fort Monroe, Va. ;

Iajor Isaac $N$ Lewis, Coast Artillery Corps, Fort Monroe, Va.;

Major John D. Barrette, Coast Artillery Corps, Fort Monroe, Va. ;

Major Thomas W. Winston, Coast Artillery Corps, Fort Monroe, Va.;
Major Charles S. Walkley, Chaplain, Coast Artillery Corps, Fort Monroe, Va.

A medical board of officers to consist of :

Captain Charles A. Rugan, Medical Corps, Fort Monroe, Va. ;

Captain George P. Peed, Medical Corps, Fort Monroe, Va.

will conduct the physical examination.

AT FORT JAY, N. Y.

Lieutcnant Colonel Louis Brechcmin, Medical Corps, New York City ;

Major George T. Holloway, Paymaster, New York City;

Tajor Delamere Skerrelt, Paymaster, New York City;

Major Amos IV. Kimball, Quartermaster, New York City.

A medical board of officers to consist of:

Lieutenant Colonel Charles Richard, Mcdieal Corps, Fort Jay, N. Y.

First Licutenant George $F$. Adair, Medical Reserve Corps, Fort Wood, N. Y.,

will conduet the physical cxamination.

$$
\text { AT FORT TOTTEN, N. Y. }
$$

Major Edgar A. Mearns, Medical Corps, Fort Totten, N. Y.;

Major Wirt Robinson, Coast Artillery Corps, Quartermaster, West Point, New York;

Major Archibald Campbell, Coast Artillery Corps, Fort Totten, N. Y.

A medical board of oflicers to consist of ;

Major James S. Wilson, Medical Corps, Fort Hamilton, N. Y.

First Lientenant William R. S. George, Medical Reserve Corps, Fort Totten, N. Y.,

will conduct the plyysical examination.

In complying with this order, Major Wilson, Captain Snyder, and Iicutenents Jarrett, IIart and Adair, will, immediately after the preliminary cxamination on October 4 , return to tlieir proper stations, and will return to point of assembly in time to make the final examinations.

Upon completion of the duties involved in this order, the officers mentioned will return to their proper stations.

The travel dirceted is necessary in the military service. (25968.)
By comaxd of Major Generai. Grant:

GEORGE S. ANDERSON,

Colonel, General Staff, Chief of Staff.
OFFICIAL:

H. O. S. HEISTAND,

Adjutant Genernl. 